\title{
The Development of Documentary Film Media in Civics Education Subject
}

\author{
Camellia $^{1 *}$, Kurnisar $^{2}$, Edwin Nurdiansyah ${ }^{3}$ \\ 1,2,3 Pancasila and Civic Education Study Program, Sriwijaya University, Indralaya 30662, Indonesia \\ *Corresponding author. Email: camellia@fkip.unsri.ac.id
}

\begin{abstract}
The purpose of this study is to develop a documentary film media in the civics education course at Sriwijaya University, which is valid and practical so that it is expected to improve students' ability to solve problems. Thus, the knowledge and abilities obtained by students can be used in the life of the community, nation and state. The research subjects were students taking civic education courses in the odd semester 2020-2021 which were determined by random sampling technique. This research is a type of research and development. The research process was carried out by language testing which obtained $82 \%$ results with valid categories, then material testing obtained $83 \%$ results with valid categories and learning media tests obtained $91 \%$ results with valid categories. Thus it can be concluded that this learning media is valid for use. Then as a refinement the researchers conducted trials with various stages, namely one to one, the results obtained were $92 \%$ in the very good category and $78 \%$ student activity level, then the small group stage obtained $93 \%$ response results with very good categories and $76 \%$ student activity level and Field evaluation obtained a response of $90 \%$ with a very good category and a $77.2 \%$ level of activity with the conclusion that the media is practical to use. The pretest results obtained an average value of 6.63 and the posttest obtained an average value of 7.96 with an increase of 1.33 with an $\mathrm{N}$ gain of 0.4 with a moderate category which indicates that this media has a potential effect on improving students' ability to solve problems in Civics lectures.
\end{abstract}

Keywords: Development, Documentary Film Media, Citizenship Education

\section{INTRODUCTION}

Based on the needs analysis study conducted by the research team through the distribution of questionnaires given to students, information was obtained that as many as $95.2 \%$ of students thought that examples of cases / problems were very necessary to make it easier to understand the concepts in civic education material, as many as $91.6 \%$ of students stated that By presenting the problems in civic education material, it will make it easier for them to understand the material and as many as $95.2 \%$ of students stated that citizenship education material will be easier to understand concretely by using a problem-based approach. Thus researchers are interested in developing documentary film media to improve students' ability to solve problems in civic education courses as a support for problem-based civics education textbooks that have been developed in previous studies. So that the process and results of civic education lectures can run more optimally.

National education is education based on Pancasila and the 1945 Constitution of the Republic of Indonesia which is rooted in religious values, Indonesian national culture and responsive to the demands of changing times"[7]. Thus, optimizing education is also 
required to keep up with the times, the current developments are marked by the rapid development of information and communication technology, the influence of this development has two sides of influence, namely positive and negative influences. The development of information and communication technology will have a positive effect if it is properly utilized, and it will have a good impact on the quality development of Human Resources and vice versa, if the use and management of information and communication technology developments is carried out improperly or less wisely, it can have a negative effect on development, existing human resources. Thus, advances in information and communication technology with all its potential, if utilized and managed properly and wisely, can be used to support the effectiveness of the implementation of education, especially character education.

It is very important to maintain that the use of information and communication technology still contributes significantly to the development of students into human character and intellectual intelligence. As well as to empower educators and related education personnel. What can be done is by utilizing information and communication technology which is designed to strengthen user interest and motivation both intellectually and psychologically.

Furthermore, teachers/lecturers must be able to provide material in interactive ways, and encourage students to be creative in solving problems.

In this research, information and communication technology is used as a tool as a learning medium, namely film or audiovisual media. Films are works of art and culture which are visual-to-hear mass communication media made based on the principle of cinematography by being recorded on celluloid tapes, video tapes, video discs and / or other technological invention materials in all forms, types and sizes through a process chemical, electronic process, or other process, with or without sound, which can be displayed and / or displayed by means of a mechanical, electronic, and / or other projection system.[8]

The film used in relation to national integration is designed to strengthen students' interest and motivation in learning, improve their ability to solve problems and instill character values, one of which is love for the country, which when analyzing the film, students are also trained to think at a higher level in solving problems. Learning activities really require the use of media as a tool or channel used by people to convey messages or information. Media is one of the communication tools in delivering certain messages, which is very useful if implemented 
into the learning process[3]. Learning media has a main function, namely as a teaching aid which also affects conditions, motivation and the learning environment[1]. Thus the use of the right learning media greatly contributes positively to maximum results on students' understanding of the material provided[5].

\section{METHODS}

This research is a development research that refers to the $\mathrm{R} \& \mathrm{D}$ Cycle of Borg and Gall[6]. This research was conducted in the Technical Implementation Unit for Personality Development Subject $(U P T-M P K)$ Sriwijaya University with a research period of 1 (one) year. The research process for developing documentary film media to develop students' ability to solve problems in civic education courses is carried out in stages 1) Preliminary study with a needs analysis to obtain information about problems or obstacles faced in lectures, 2). Product development begins with discussing findings or information from the results of preliminary studies which are then designed, compiled and then developed according to the needs in the field. Furthermore, the product / media produced is tested for product validity by a team of experts and finally the production of documentary film media, 3). Product testing, the trial implementation is carried out in several stages, namely one to one trials, small groups and field evaluations. Media trials were carried out several times with the aim of producing documentary film media that could improve students 'ability to solve problems in civic education courses that were valid, practical, and had a potential impact on improving students' good personalities in solving problems.

Collecting data in research activities is carried out by 1) documentation. Documents are "records of events that have passed. The documentation technique is used to collect written data from a situation and the activities of the research subject "[4], Next, 2) Questionnaires are used to obtain data from validators and respondents regarding the validity and application of documentary film media in civic education courses, 3) Observation or observation is a" phenomena recording activity conducted systematically"[2]. In this study, the observation that will be used is participatory observation (involved), meaning that the researcher is directly involved in the activities of the person being the research target, without causing changes to the activity or activity concerned, and 4) The test is carried out at the documentary film media trial stage. to respondents to find out the mastery of learners (students) after participating in the learning process. Then the results will be analyzed according to predetermined criteria. 


\section{RESULT AND DISCUSSION}

Based on the needs analysis carried out by the research team through the distribution of questionnaires given to students, information was obtained that on average 94\% of student students thought that examples of cases / problems were very necessary to make it easier to understand the concept in civic education material, by presenting problems in the material make it easier for them to understand civics education materials and materials will be more easily understood in a concrete manner using a problem-based approach. Furthermore, through the process of developing learning media in the form of documentary films to improve students' ability to solve problems in civic education lectures, researchers started by testing product validity with three validators, namely language validators, material validators and media validators. Each result was obtained, namely for language validation the result was $82 \%$, then the material validation was $83 \%$ and the media validation obtained $91 \%$ results, all of which were categorized as valid.

Furthermore, after the product was declared valid or feasible to be tested, the researcher conducted a product trial with several stages, namely one to one, the results obtained $92 \%$ responses with very good categories and $78 \%$ student activity level, then the small group stage obtained $93 \%$ response results with very good categories As well as $76 \%$ student activity level and field evaluation responses obtained $90 \%$ with a very good category and $77.2 \%$ activity level with the conclusion that the media is practical to use. The pretest results obtained an average value of 6.63 and the posttest obtained an average value of 7.96 with an increase of 1.33 with an $\mathrm{N}$ gain of 0.4 with a moderate category which indicates that this media has a potential effect on improving students' ability to solve problems in Civics lectures.

\section{CONCLUSION}

Based on the results of the validation test, the documentary film media developed by the research team was declared valid for use. Then through the data and information on the results of the trials and the responses obtained at each stage of the one to one, small group and field evaluations, it was found that the documentary media developed by the research team was practical for use and through the comparison of the increase in the pretest and posttest results showed that the media The documentary film developed by the research team has a potential effect on improving students' problem-solving abilities in Civics lectures. 


\section{ACKNOWLEDGMENT}

This work is supported by the Rector of the Sriwijaya University, the UPT MPK of Sriwijaya University and the Pancasila and Civics Education study program, the Faculty of teacher training and education of Sriwijaya University.

\section{REFERENCES}

[1] Hamalik, O, 1990. Curriculum development. Bandung: Mandar Maju.

[2] Idrus, M. (2009). Social Science Research Methods. Jakarta: Erlangga

[3] Rusman, et al. 2011. Learning Based on Information and Communication Technology. Jakarta: PT Raja Grafindo.

[4] Sugiyono. (2012). Quantitative Research Methods, Qualitative and $\mathrm{R} \& \mathrm{D}$. Bandung; CV. Alfabeta.

[5] Sundayana, R., 2013. Mathematics Learning Media for Teachers, Teacher Candidates, Parents, and Mathematics Lovers. Bandung: Alfabeta.

[6] Sukmadinana, Nana S. (2007). Educational Research Methods. Bandung: PT Remaja Rosdakarya

[7] Law on National Education System (Education) No. 20 of 2003.

[8] Law No.8 of 1992 concerning Film 